\title{
Editorial: Advanced research on offshore structures and foundation design: part 1
}

\author{
T. Fazeres-Ferradosa \\ CIIMAR - Interdisciplinary Centre of Marine and Environmental \\ Research of the University of Porto, Terminal de Cruzeiros do \\ Porto de Leixões, Avenida General Norton de Matos, Matosinhos, \\ Portugal; FEUP - Faculty of Engineering of the University of Porto, \\ Department of Civil Engineering, rua Dr. Roberto Frias, Porto, \\ Portugal

\section{P. Rosa-Santos} \\ CIIMAR - Interdisciplinary Centre of Marine and Environmental \\ Research of the University of Porto, Terminal de Cruzeiros do \\ Porto de Leixões, Avenida General Norton de Matos, Matosinhos, \\ Portugal; FEUP - Faculty of Engineering of the University of Porto, \\ Department of Civil Engineering, rua Dr. Roberto Frias, Porto, \\ Portugal
}

\section{F. Taveira-Pinto}

CIIMAR - Interdisciplinary Centre of Marine and Environmental Research of the University of Porto, Terminal de Cruzeiros do Porto de Leixões, Avenida General Norton de Matos, Matosinhos, Portugal; FEUP - Faculty of Engineering of the University of Porto, Department of Civil Engineering, rua Dr. Roberto Frias, Porto, Portugal

\section{E. Vanem}

DNV GL Group Technology and Research, Veritasveien, Høvik, Norway

\section{H. Carvalho}

Department of Structural Engineering, Federal Univeristy of Minas Gerais, Belo Horizonte - MG

\section{J. Correia}

FEUP - Faculty of Engineering of the University of Porto, Department of Civil Engineering, rua Dr. Roberto Frias, Porto, Portugal

\section{Introduction}

Engineering practice and design of offshore structures and foundations stands as a mirror of mankind's ambition to unveil the unknown resources existent at sea. The first main drive to develop offshore engineering goes back to the 1890's. In the USA, the offshore oil and gas industry expanded to the coastline and the Outer Continental Shelf. By then, the first oil wells were drilled in ocean from wooden piers attached to shore, which would later become impossible due to increasing distances to shore (NASEM, 2016). The first free-standing structure for oil drilling was placed in the Gulf of Mexico, 1.5 miles offshore, whereas in 1947 the first out of site well was installed 12 miles of the coast of Louisiana (Priest, 2008). The number of oil rigs throughout the World currently surpasses the 1300 units (Table 1), whereas new ones arise constantly and others are decommissioned. The first incursions, towards offshore locations, marked the beginning of a new energetic era that endures till nowadays. This historical period had extended contributions to key fields for economical and social progress, including the sustainable development of marine renewable energy (Taveira-Pinto et al., 2019), development of met-ocean data acquisition, monitoring and prediction (Bitner-Gregersen et al., 2016; Vanem et al., 2019; Wang et al., 2018) and general knowledge on structures' design and construction at deep sea (Chakrabarti, 2005).

In addition to the key role of oil and gas energy resources, the estimates of the theoretical potential of marine renewable energy sum-up to more than $343000 \mathrm{TWh} / \mathrm{yr}$, if energy resources such as marine biomass, offshore wind and offshore solar, waves, and tides and marine currents are considered (Taveira-Pinto et al., 2019). While in some fields, like wave energy, the technology readiness levels are quite low, in others, such as the offshore wind and tidal power dams, the commercial stage has been achieved and is moving towards more competitive levelized costs of energy. The current stage of oil and gas industry, allied to the untapped renewable energy at sea, is now contributing to an attractive energy mix around the world, thus leading to increasing investments in the offshore industry. A good example of this market growth lies in the European offshore wind, which in 2018 had an increase in the number of offshore wind foundations placed at sea. Additional 416 foundations, with connected turbines to the grid, were placed (Table 2) and 361 were newly installed (Table 3).

In fact, major players of the oil and gas industry, such as Shell, Total, British Petroleum, ExxonMobil, Eni, Equinor and Petrobrás are now driving the investments in renewable energy, allocating a large portion of their revenue in energy sources as the offshore wind and solar energy (Pickl, 2019).

Furthermore, the international context on policies to improve the adaptation to climate change is also contributing to a growing number and type of projects, structures and foundations. Also new projects arise for offshore structures repowering and lifetime extension (Fazeres-Ferradosa et al., 2019), and even for reconversion of former oil and gas platforms to renewable energy production units (Leporini et al., 2019). New market trends as the installation of offshore foundations at increasing water depths, increasing size of structure's components (such as rotors, blades, monopile diameters), the use of new building materials, the advanced design on subsea structures (manifolds, pipelines and risers, aquaculture frames), among other aspects, also set the pace for the challenges arising in this field.

The advanced research on this topic is of greater importance not only due to the direct impact in the global energy sector, but also due to the considerable spin-off effects on many fields related to maritime engineering. 
Table 1. Location and distribution of Offshore oil rigs worldwide in 2018 (Statista, 2019)

$\begin{array}{lclc}\text { Location } & \text { Number of offshore oil rigs } & \text { Location } & \text { Number of offshore oil rigs } \\ \text { North Sea } & 184 & \text { Rest of South America and Caribbean } & 30 \\ \text { Gulf of Mexico (U.S.) } & 175 & \text { Rest of U.S } & 28 \\ \text { Persian Gulf } & 159 & \text { Mediterranean } & 26 \\ \text { Far East Asia } & 155 & \text { Black Sea } & 18 \\ \text { Southeast Asia } & 152 & \text { Red Sea } & 17 \\ \text { Mexico } & 88 & \text { Australia } & 11 \\ \text { Western Africa } & 75 & \text { Canadian Atlantic } & 7 \\ \text { South Asia } & 58 & \text { Alaska (U.S.) } & 5 \\ \text { Brazil } & 51 & \text { Rest of Africa } & 5 \\ \text { Venezuela } & 46 & \text { Eastern Europe } & 3 \\ \text { Caspian Sea } & 37 & \text { Canadian Pacific \& Artic } & 2\end{array}$

Table 2. Foundations with connected turbines to the grid in 2018 in the European offshore wind sector (WindEurope, 2019).

$\begin{array}{lrcc}\text { Wind Farm } & \text { Connected capacity in } \mathbf{2 0 1 8}(\mathbf{M W}) & \text { No. of turbines connected in } \mathbf{2 0 1 8} & \text { Type of Foundation } \\ \text { Walney Extension Phase East } & 329 & 47 & \text { Bottom-fixed } \\ \text { Galloper } & 277 \cdot 2 & 44 & \text { Bottom-fixed } \\ \text { Beatrice } & 273 & 39 & \text { Bottom-fixed } \\ \text { Rampion } & 220 \cdot 8 & 64 & \text { Bottom-fixed } \\ \text { EOWDC } & 93 \cdot 2 & 11 & \text { Bottom-fixed } \\ \text { Walney Extension Phase West } & 66 & 8 & \text { Bottom-fixed } \\ \text { Race Bank } & 50 \cdot 4 & 8 & \text { Bottom-fixed } \\ \text { Kincardine Pilot } & 2 & 1 & \text { Floating } \\ \text { Borkum Riffgrund II } & 464 \cdot 8 & 56 & \text { Bottom-fixed } \\ \text { Arkona } & 384 & 60 & \text { Bottom-fixed } \\ \text { Merkur Offshore } & 120 & 20 & \text { Bottom-fixed } \\ \text { Rentel } & 308 \cdot 7 & 42 & \text { Bottom-fixed } \\ \text { Horns Rev 3 } & 33 \cdot 2 & 4 & \text { Bottom-fixed } \\ \text { Nissum Bredning } & 28 & 4 & \text { Bottom-fixed } \\ \text { Elisa Elican } & 5 & 1 & \text { Bottom-fixed } \\ \text { Blockstigen } & 3 \cdot 3 & 5 & \text { Bottom-fixed } \\ \text { Floatgen } & 2 & 1 & \text { Floating } \\ \text { Eolink Prototype } & 0 \cdot 2 & 1 & \text { Floating }\end{array}$

However, the knowledge on the design of offshore structures and foundations is often restricted to a small number of scientists and professionals. This is, to a large extent, related with the confidential policies adopted by the majority of the stakeholders. Therefore, the need to address specific developments of offshore structures and foundations' design is a key step to enhance knowledge sharing across the world-wide community, thus contributing for break-through research in the field.

\section{Design and offshore structures and foundations}

Marine structures such as vessels, subsea and offshore structures present numerous peculiarities that contribute to a higher complexity and enhanced difficulties in their design. They have very large dimensions, are capital-intensive and placed in the most unfriendly and destructive environment, the sea (Pedersen, 2015).

Regardless of the purpose (e.g. marine energy harvesting, oil and gas transfer to shore, monitoring actives), any structure
Table 3. Offshore wind foundations installed in 2018 in Europe (WindEurope, 2019).

\begin{tabular}{|lcl|} 
Wind Farm & $\begin{array}{c}\text { Foundations } \\
\text { installed in 2018 }\end{array}$ & $\begin{array}{l}\text { Type of } \\
\text { Foundation }\end{array}$ \\
\hline Est Anglia 1 & 37 & Bottom-fixed \\
Hornsea One & 156 & Bottom-fixed \\
Deutche Bucht & 29 & Bottom-fixed \\
Hohe See & 63 & Bottom-fixed \\
Trianel Windpark Borkum 2 & 32 & Bottom-fixed \\
Norther & 44 & Bottom-fixed \\
Total amount & 361 & Bottom-fixed \\
\hline
\end{tabular}

placed at sea needs to be properly designed to endure common loads, such as self-weight, cargo-weight, fatigue or wind. However, a particular attention is required to maritime specific loads and phenomena, such as wave-loading, ocean currents, scour and erosion, soil liquefaction, thermal gradients, marine growth or corrosion. Such design is, therefore, very site specific 
with certain aspects that might be difficult to approach in a standard generalised manner.

Into the bargain there is also a variety of standards, recommended practices and norms that can be used in designing an offshore structure. While in Northern European countries (e.g. Norway, Denmark, Belgium or Germany) the use of Det Norske Veritas GL rules and standards might prevail, e.g. DNV GL-ST-0119 (DNV GL, 2018), countries like Angola or the United States of America use the American Petroleum Institute (API) standards, e.g. API-RP-2FPS. Therefore, design of offshore structures and foundations requires technical expertise that is combined with the knowledge of the legal instruments applicable to the precise location of the project.

Such complex regulation and heavy technical requirements were often improved as a result of learned lessons from a not so distant past. Over the past few decades, major offshore incidents that claimed hundreds of lives, damaged the environment critically and caused billions of dollars of property and environmental losses, e.g. Sea Gem collapse, Santa Barbara blowout, Alexander L. Kielland capsize, Piper Alpha disaster (Tamim et al., 2019). This pushed the industry to develop new sets of rules, standards and safety requirements to prevent such catastrophes (Christou and Konstantinidou, 2012; Tamim et al., 2019). Table 4 summarizes some of the previous major accidents reported in the literature.

However, in spite of improvements and developments made in regulations, technical standards, norms and recommended practices, there are empirical approaches that require further study and knowledge deepening, whereas new fields of the industry arise with the lack of specific norms developed, e.g. dynamic scour protections for offshore wind (Fazeres-Ferradosa et al., 2018a, 2018b), new constructive materials applied to subsea structures (e.g. Pavlou, 2019), or the analysis of met-ocean data in cases were recommended approaches have a lack of goodness-of-fit (e.g. Vanem et al., 2019).

\section{Themed issue Advanced Research on Offshore Structures \& Foundation Design}

The previously described context of relevant market and industry's growth, along with the restrict knowledge sharing and the need for a constant update and improvement on engineering practices, motivated further the need to perform research dedicated to offshore structures and foundations. Therefore, the present issue compiles works on topics related to the keynote lectures provided at the International Offshore Structures Design (IOSD) course, held in the Faculty of Engineering of the University of Porto, in May 2019. The IOSD course series started in 2016 and resulted from the R\&D activities within the Marine Energy Research Group from the Interdisciplinary Centre of Marine and Environmental Research of the University of Porto (CIIMAR).
The 2019 edition also counted with the partnership of the Institute of Hydraulics and Water Resources (IHRH).

In the first part of this themed issue, two research papers are presented addressing innovative fields of applied engineering: i) new materials applied to offshore structures (Pavlou, 2019) and ii) statistical description of met-ocean data (Vanem et al., 2019).

The need for an improved structural behaviour in offshore environmental conditions has been a main driver to promote the use of new composite materials in offshore structures, pipelines or production risers, among others. The composite materials have become an attractive solution and a novel concept whose application is growing in the offshore industry (Amaechi et al., 2019), by several reasons. For instance, the offshore industry has moved from shallow waters to deep waters and thus lighter structures are required, such as composite risers and wind turbine blades (Amaechi et al., 2019). In fact, fibrereinforced polymer (FRP) materials have been used in pipelines and risers due to the potential weight savings and improved resistance to corrosion. In addition, they also present considerably better dynamic behaviour than steel, due to comparatively high bending stiffness, while having good performance in fatigue and yield stress (Pavlou, 2019).

In this context, a comprehensive flow-induced dynamic instability analysis for curved FRP risers is presented in Pavlou (2019). Curved risers present considerable centrifugal forces, which yield dynamic motion that is counteracted by the Coriolis forces caused by the inner fluid flow. Therefore, the dynamic response of the riser results from a balance between the centrifugal, Coriolis, inertial, flexural restoring and drag forces, thus being a complex system to be analysed and further designed. Existing methods for dynamic response analysis are based on simplifications, which ignore the multi-phase flow, the internal instability and the anisotropy of the material of the flexible riser Pavlou (2019). Researchers working on hydrodynamics often take into account only the effect of the external cross flow and ignore the inner axial flow-pipe interaction and the effect of the mass of the pump. Furthermore, only methods for the dynamic response of risers made for isotropic material are available in the literature. This gap is attempted to be filled by Pavlou (2019). In this work, the instability of curved risers made of multi-layered FRP material is analysed and the motion equation and boundary conditions are treated with the Transfer Matrix Method. The proposed method is also applied to representative examples and the results discussed. This paper is of great utility for researchers and professionals seeking for more accurate and detailed methods to analyse structures, such as deep-sea mining risers or free hanging catenary risers with hanged pump. Moreover, it provides interesting cost and benefit comparisons between FRP and steel materials in offshore risers. As result, Pavlou (2019) proposes a methodology that can be applied in the automatic 
Table 4. Examples of landmark accidents from offshore engineering past (compiled and adapted from Christou and Konstantinidou (2012), Oil Rig Disasters (2019) and completed with own research).

\begin{tabular}{|c|c|c|c|c|}
\hline Accident & Location & Losses & Description & Relevant outcomes \\
\hline $\begin{array}{l}\text { Sea Gem Rig } \\
\text { Collapse }\end{array}$ & $\begin{array}{l}\text { UK Continental } \\
\text { Shelf, 1965 } \\
\text { (United Kingdom) }\end{array}$ & Total property loss and 13 life losses & $\begin{array}{l}\text { Two of the rig's ten legs failed, leading the rig } \\
\text { to fall sideways. Subsequently, the rig was } \\
\text { reported to capsize and sank with one leg } \\
\text { remaining above the sea }\end{array}$ & - \\
\hline $\begin{array}{l}\text { Santa Barbara } \\
\text { Oil Spill }\end{array}$ & $\begin{array}{l}\text { California coastline, } \\
1969 \text { (USA) }\end{array}$ & $\begin{array}{l}\text { More than } 71,400 \text { barrels of crude loss and } \\
\text { unprecedented environmental destruction }\end{array}$ & $\begin{array}{l}\text { A first well blew out, spewing oil and gas, which } \\
\text { then led to an explosion that cracked the sea } \\
\text { floor in } 5 \text { places and released } 1,000 \text { gallons of } \\
\text { oil an hour. A second blow out in a different } \\
\text { well followed on two months later }\end{array}$ & $\begin{array}{l}\text { This event is considered to have led to the } \\
\text { signing of the National Environmental Policy } \\
\text { Act, which required the creation of } \\
\text { environmental impact reports on major } \\
\text { projects. It is also known for its positive impact } \\
\text { on environmental awareness by regular } \\
\text { Americans towards offshore drilling and } \\
\text { exploitation }\end{array}$ \\
\hline $\begin{array}{l}\text { Ekofisk B } \\
\text { Blowout }\end{array}$ & $\begin{array}{l}\text { North Sea, } 1977 \\
\text { (Norway) }\end{array}$ & $\begin{array}{l}\text { Estimated production loss between } 80,000 \text { to } \\
126,000 \text { barrels, largest blowout in North } \\
\text { Sea }\end{array}$ & $\begin{array}{l}\text { Oil well blowout occurred at the Ekofisk Bravo } \\
\text { platform, due to an incorrectly installed } \\
\text { downhole safety valve. This resulted in the } \\
\text { well blowing out with an uncontrolled release } \\
\text { of oil and gas. Human errors were the major } \\
\text { factor which led to the mechanical failure of } \\
\text { the safety valve. These errors included faults in } \\
\text { the installation documentation and equipment } \\
\text { identification and misjudgements, improper } \\
\text { planning and improper well control }\end{array}$ & - \\
\hline Ixtoc I Blowout & $\begin{array}{l}\text { Gulf of Mexico, } 1979 \\
\text { (Mexico) }\end{array}$ & $\begin{array}{l}\text { Extensive damage along the US coast with } \\
\text { the Texas coast suffering the greatest. } \\
\text { Biggest single spill before the occurrence of } \\
\text { Macondo accident, with an estimated } 3 \cdot 5 \\
\text { million barrels of oil lost }\end{array}$ & $\begin{array}{l}\text { Well suffered a blowout, with oil and gas } \\
\text { flowing to unrestricted surface igniting and } \\
\text { engulfing the semi-sub Sedco } 135 \mathrm{~F} \text { in flames. } \\
\text { Later the rig collapsed and sank onto the } \\
\text { wellhead area on the seabed. Oil and gas } \\
\text { leakage lasted for } 9 \text { months ending in an oil } \\
\text { slick of } 180 \mathrm{~km} \text { by } 80 \mathrm{~km}\end{array}$ & - \\
\hline Bohai 2 Jack-up & $\begin{array}{l}\text { Gulf of Bohai, } 1979 \\
\text { (China) }\end{array}$ & 72 life losses (2 survivors) & $\begin{array}{l}\text { Jack-up faced major storm waves and wind } \\
\text { loads which overtopped the main deck and } \\
\text { broke a ventilator pump free, causing it to fall } \\
\text { and puncture the deck, which caused a flood } \\
\text { in the pump-room. The rig became unstable } \\
\text { and due to harsh weather conditions the jack- } \\
\text { up capsized and sank }\end{array}$ & $\begin{array}{l}\text { Improvements were made in regulations and } \\
\text { standards related to emergency and } \\
\text { evacuation procedures, usage of lifesaving } \\
\text { equipment and proper equipment storage at } \\
\text { platforms }\end{array}$ \\
\hline $\begin{array}{l}\text { Alexander } \\
\text { L. Kielland } \\
\text { capsize - } \\
\text { floating hotel }\end{array}$ & $\begin{array}{l}\text { North Sea, } 1980 \\
\text { (Norway) }\end{array}$ & 123 life losses (89 survivors); Total asset loss & $\begin{array}{l}\text { Failure of supporting leg due to severe gale force } \\
\text { winds, but not severe storm. Problems were } \\
\text { detected in a weld of an instrument connection } \\
\text { on the bracing which contained cracks }\end{array}$ & $\begin{array}{l}\text { Improvement of failure cause analysis and } \\
\text { increasing standards for evacuation and rescue } \\
\text { operations }\end{array}$ \\
\hline $\begin{array}{l}\text { Piper Alpha } \\
\text { explosion }\end{array}$ & $\begin{array}{l}\text { North Sea, } 1988 \\
\quad \text { (Scotland) }\end{array}$ & $\begin{array}{l}167 \text { life losses, including } 2 \text { operators of a Fast } \\
\text { Rescue Craft ( } 62 \text { survivors) and property } \\
\text { damage estimated in } € 2 \text { billion }\end{array}$ & $\begin{array}{l}\text { Condensate leak resulting from maintenance } \\
\text { work being carried out simultaneously on a } \\
\text { pump and related safety valve led to gas } \\
\text { ignition and explosion, causing fire and } \\
\text { sequential explosions in risers and structural } \\
\text { damage with the further release of gas and oil }\end{array}$ & $\begin{array}{l}\text { The Cullen inquiry resulted in more than } 100 \\
\text { recommendations that re-shaped offshore } \\
\text { safety legislation and practices, namely in chains } \\
\text { of command and communication procedures } \\
\text { for platform's crew. Necessity of creating fire } \\
\text { and blast walls at the platforms. Increased } \\
\text { regulations on safety at offshore installations }\end{array}$ \\
\hline
\end{tabular}




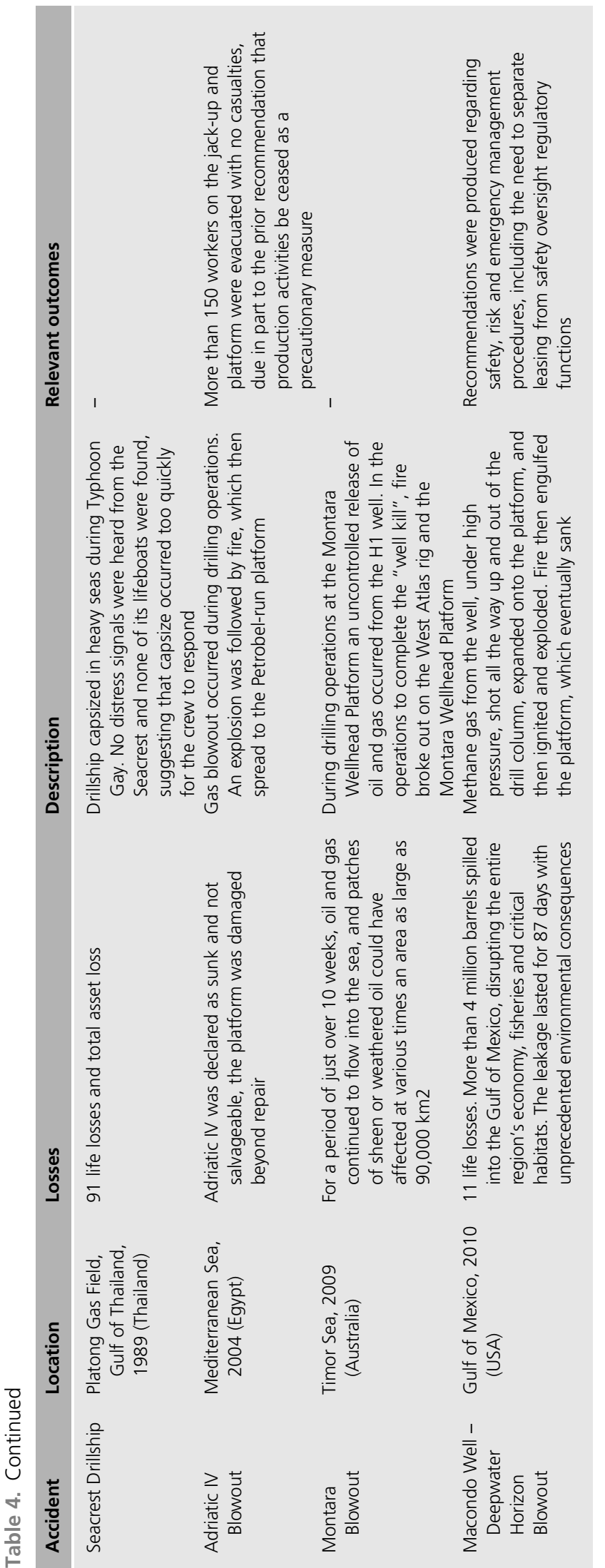

control of deep-sea mining risers or the deflection control of oil and gas production risers, while it also allows for design optimisation to avoid flow-induced resonance.

Another important aspect for design practice is the multivariate analysis of met-ocean conditions. The understanding of ocean wave climate is a crucial step in the design of offshore structures, foundations and its components. Finding joint models for seastate characteristics is often difficult due to the complex nature of the wave climate and its physical constraints. The available records of wave characteristics are often very asymmetric in their nature, which makes it difficult the use of common marginal distributions, e.g. normal, logarithmic or Weibull distributions (Fazeres-Ferradosa et al., 2018b). Moreover, the structural safety of offshore structures is heavily dependent on the uncertainty related to environmental loads, which acquires additional importance when Climate Change effects are considered. Nevertheless, there are cases, in which widely used methods, foreseen in offshore standards do not present an acceptable goodness-of-fit, thus not being suitable for a proper statistical description of site conditions, e.g. the use of the Conditional Modelling Approach (DNV GL, 2017) applied to Horns Rev 3 data (see FazeresFerradosa et al., 2018b). This justifies the study and development of more complex multivariate models, which are reviewed and analysed in Vanem et al. (2019).

Vanem et al. (2019) present a detailed review on the statistical description and multi-variate modelling of extreme ocean wave conditions, along with some brief examples of state-of-the-art joint modelling techniques and a discussion of such models utility in marine engineering applications. In addition, the authors highlighted the importance of environmental contours as a tool to characterize extreme ocean environments for structural design and risk assessment purposes. This paper includes also applications to stationary and non-stationary univariate analysis as well as multivariate analysis and spatial extreme value analysis. Some other examples of the models under analysis are the copula-based ones, the conditional modelling approach or the conditional extremes. The present review becomes an attention-grabbing paper, for those dealing with met-ocean data and design, as it provides a solid background on the subject and a better understanding on the advantages and the pitfalls of various techniques. Furthermore, Vanem et al. (2019) dedicates a full section to examples for marine engineering applications, where the applicability to reliability methods, as the First- and Second-Order-Reliability-Method, is also pointed.

\section{Conclusions}

The engineering practice and design of offshore structures and foundations registered an intense progress over the past 70 years. Such developments were in fact a result of the main drive provided by the Oil and Gas industry, which somehow opened the way for further maritime and offshore activities, 
which eventually derived into the recent growth of Marine Renewable Energy.

While oil and gas still play a major role in World's energy consumption, the untapped potential of energy related to the marine resources has enlarged the need to place structures and foundations at sea. These factors, combined with the current context of international policies on Climate Change and the new markets, require improved engineering practices and design methods. This results in contributions to the development of new methodologies, standards and norms, which are able to account for the general complexity of marine environment but also for site-specific conditions. Therefore, new challenges arise in this research field, which largely benefits from lessons learned in a recent past that, unfortunately, counts with dozens of failure events often resulting in large economic, environmental and life losses.

The advanced research on offshore structures and design is of upmost importance for break-through innovation and contributions to the energy sector and its related fields. The part 1 of this special topic focused on important aspects of state-of-theart design, which represent key research lines for offshore engineers, researchers and associated professionals. This issue will be completed with part 2 , which will focus on remaining important aspects of offshore structures and foundations design, e.g. scour protections, floating foundations, fatigue design.

\section{REFERENCES}

Amaechi CV, Agbomerie CO, Sotayo A et al. (2019) Recycling of Renewable Composite Materials in the Offshore Industry. Reference Module in Materials Science and Materials Engineering, https://doi.org/10.1016/B978-0-12-803581-8.11445-6.

API (American Petroleum Institute) (2011) API-RP-2FPS Planning, Designing, and Constructing Floating Production Systems. American Petroleum Institute, Washington, DC, USA.

Bitner-Gregersen EM, Dong S, Fu T et al. (2016) Sea state conditions for marine structures' analysis and model tests. Ocean Engineering 119: 309-322, https://doi.org/10.1016/j.oceaneng.2016.03.024.

Chakrabarti S (2005) Handbook of Offshore Engineering. Elsevier, USA, p. 132.

Christou M and Konstantinidou M (2012) Safety of offshore oil and gas operations: lessons from past accident analysis - Ensuring $E U$ hydrocarbon supply through better control of major hazards. Joint Research Centre of the European Commission, Luxemburg, Report EUR 25646 EN, https://doi.org/10.2790/73321.

DNV GL (2017) DNVGL-RP-C205: Environmental Conditions and Environmental Loads. DNV GL, Høvik, Norway.

DNV GL (2018) DNV GL-ST-0119 Floating wind turbine structures. DNV GL, Høvik, Norway.

Fazeres-Ferradosa T, Taveira-Pinto F, Romão X et al. (2018a) Probabilistic design and reliability analysis of scour protections for offshore windfarms. Engineering Failure Analysis 91: 291-305, https://doi. org/10.1016/j.engfailanal.2018.04.035.

Fazeres-Ferradosa T, Taveira-Pinto F, Vanem E, Reis MT and das Neves L (2018b) Asymmetric copula-based distribution models for met-ocean data in offshore wind engineering applications. Wind Engineering 42(4): 304-334, https://doi.org/10.1177/ $0309524 X 18777323$.
Fazeres-Ferradosa T, Taveira-Pinto F, Rosa-Santos P and Chambel J (2019) A review of reliability analysis of offshore scour protections. Proceedings of the Institution of Civil Engineers - Maritime Engineering 172(3): 104-117, https://doi.org/10.1680/jmaen.2019.11.

Hastie JC, Kashtalyan M and Guz IA (2019) Failure analysis of thermoplastic composite pipe (TCP) under combined pressure, tension and thermal gradient for an offshore riser application. International Journal of Pressure Vessels and Piping 178, https://doi.org/10.1016/j.ijpvp.2019.103998.

Leporini M, Marchetti B, Corvaro F and Polonara F (2019) Reconversion of offshore oil and gas platforms into renewable energy sites production: Assessment of different scenarios. Renewable Energy 135: 1121-1132, https://doi.org/10.1016/j.renene.2018.12.073.

NASEM (National Academies of Sciences, Engineering, and Medicine) (2016) Strengthening the Safety Culture of the Offshore Oil and Gas Industry. The National Academies Press, Washington, DC, USA, https://doi.org/10.17226/23524.

Oil Rig Disasters (2019) Oil Rig Disasters: Offshore drilling accidents. See http://members.home.nl/the_sims/rig/index.htm (accessed 19/12/2019).

Pavlou D (2019) Curved fibre-reinforced-polymer risers: inner flow-induced dynamic instability analysis. Proceedings of the Institution of Civil Engineers - Maritime Engineering, https://doi.org/10.1680/jmaen.2019.16.

Pedersen PT (2015) Marine Structures: Future Trends and the Role of Universities. Engineering 1(1): 131-138, https://doi.org/ 10.15302/J-ENG-2015004.

Pickl MJ (2019) The renewable energy strategies of oil majors - From oil to energy? Energy Strategy Reviews 26, https://doi.org/ 10.1016/j.esr.2019.100370.

Priest T (2008) Claiming the Coastal Sea: The Battle for the Tidelands 1937-1953. In History of the Offshore Oil and Gas Industry in Southern Louisiana, OCS Study MMS 2008-042 (Austin DE, Priest T, Penney L, Pratt J, Pulsipher AG, Abel J and Taylor J (eds)). U.S. Department of the Interior, Minerals Management Service, Gulf of Mexico OCS Region, New Orleans, LA, USA, vol. 1, pp. 67-92.

Statista (2019) Number of offshore rigs worldwide as of January 2018 by region. Statista, See https://www.statista.com/statistics/279100/ number-of-offshore-rigs-worldwide-by-region (accessed 03/12/2019).

Tamim N, Sam Mannan M and Nazmul Karim M (2019) An analysis of offshore safety incidents in the last 50 years and a look into the current perspectives. Institution of Chemical Engineers Symposium Series, Birmingham, UK, vol. 2019-May, issue (166).

Taveira-Pinto F, Rosa-Santos P and Fazeres-Ferradosa T (2019) Marine renewable energy. Renewable Energy, https://doi.org/10.1016/ j.renene.2019.10.014 (in press).

Vanem E, Fazeres-Ferradosa T, Rosa-Santos P and Taveira-Pinto F (2019) Statistical Description and Modelling of Extreme Ocean Wave Conditions for Marine Engineering Applications. Proceedings of the Institution of Civil Engineers - Maritime Engineering 1-19. https://doi.org/10.1680/jmaen.2019.20.

Wan C, Shankar K and Morozov EV (2017) Global design and analysis of deep sea FRP composite risers under combined environmental loads. Advanced Composite Materials 26(1): 79-98, https://doi.org/ 10.1080/09243046.2015.1052187.

Wang P, Tian X, Peng T and Luo Y (2018) A review of the state-of-the-art developments in the field monitoring of offshore structures. Ocean Engineering 147: 148-164, https://doi.org/10.1016/ j.oceaneng.2017.10.014

WindEurope (2019) Offshore Wind in Europe - Key trends and statistics. windeurope.org, See https://windeurope.org/wp-content/uploads/ files/about-wind/statistics/WindEurope-Annual-Offshore-Statistics2018.pdf (accessed 06/12/2019). 